\title{
Efficacy and safety of anti-TNF agents in the Lombardy rheumatoid arthritis network (LORHEN)
}

\section{Efficacia e sicurezza degli agenti anti-TNF nel registro Lombardo (LORHEN)}

\author{
P. Sarzi-Puttini ${ }^{1}$, M. Antivalle ${ }^{1}$, A. Marchesoni ${ }^{2}$, E.G. Favalli ${ }^{2}$, R. Gorla ${ }^{3}$, M. Filippini ${ }^{3}$, \\ R. Caporali ${ }^{4}$, F. Bobbio-Pallavicini ${ }^{4}$, C. Montecucco ${ }^{4}$, F. Atzeni ${ }^{1}$ \\ ${ }^{1}$ Rheumatology Unit, L. Sacco University Hospital, Milan, Italy; \\ ${ }^{2}$ UOC Day Hospital of Rheumatology, G. Pini Orthopedic Institute, Chair of Rheumatology, University of Milan, Milan, Italy; \\ ${ }^{3}$ Rheumatology and Immunology Unit, Spedali Civili di Brescia, Brescia, Italy; \\ ${ }^{4}$ Chair of Rheumatology, IRCCS Policlinico S. Matteo, Pavia, Italy
}

\begin{abstract}
SOMMARIO
L'artrite reumatoide $(A R)$ è una patologia ad andamento cronico, caratterizzata da sinovite persistente, progressiva distruzione delle strutture articolari e disabilità. Gli agenti biologici anti-Tumor Necrosis Factor- $\alpha(T N F-\alpha)$ (etanercept, infliximab e adalimumab) sono dotati di attività anti-infiammatoria, mediata dalla neutralizzazione del TNF- $\alpha$, e presentano alcuni importanti vantaggi rispetto ai "Disease-Modifying Anti-rheumatic Drugs" DMARDs. Gli agenti-anti-TNF- $\alpha$ sia in monoterapia sia in associazione al methotrexate (MTX), agiscono più rapidamente rispetto ai DMARDs e sono in grado di ridurre l'attività di malattia non solo nei pazienti che hanno una risposta parziale ai farmaci di fondo, ma anche in quelli non responsivi. Nello stesso momento in cui in Europa veniva approvato il terzo farmaco anti-TNF per trattare i pazienti affetti da artrite reumatoide (AR), la Società Italiana di Reumatologia (SIR) avviava un database per registrare e monitorare i pazienti affetti da AR trattati con i farmaci anti-TNF. Fin dal 1999, tutti i pazienti affetti da AR secondo i criteri dell'American College of Rheumatology (ACR) trattati con almeno una dose di farmaco anti-TNF presso quattro Centri di Reumatologia siti in Lombardia (nord est Italia) sono stati inclusi nel registro Lombardy Rheumatology Network (LORHEN) per valutare l'efficacia e la sicurezza dei tre agenti anti-TNF attualmente in commercio durante i primi tre anni di trattamento.
\end{abstract}

Reumatismo, 2008; 60(4):290-295

\section{INTRODUCTION}

Clinis linical trials have shown that anti-tumour necrosis factor (TNF)- $\alpha$ drugs are effective in patients with rheumatoid arthritis (RA) refractory to disease-modifying antirheumatic drugs (DMARDs) (1-4). At about the same time as the European approval of the third anti-TNF $\alpha$ agent (adalimumab) for treating RA patients, the Italian Society of Rheumatology (Società Italiana di Reumatologia [SIR]) started a database for the registration and active follow-up of RA patients treated with biological response modifiers, which contains all of the demographic and clinical parameters, as well as the therapeutic data, usually needed to follow RA patients

Indirizzo per la corrispondenza:

Piercarlo Sarzi-Puttini, MD

Director of Rheumatology Unit;

L. Sacco University Hospital, Milan

e-mail: sarzi@tiscali.it in clinical practice (5). SIR has also produced guidelines for the use of anti-TNF $\alpha$ agents: a diagnosis of RA (American College of Rheumatology [ACR] criteria); failure to respond to at least one course of combination therapy with full-dose traditional DMARDs, one of which should always be methotrexate (MTX) unless contraindicated; and active disease as defined by a 28 -joint Disease Activity Score (DAS28) of $>3.7$ (5).

Active infection, a history of malignancy or premalignant condition, class III/IV congestive heart failure, and demyelinating disorders are absolute exclusion criteria. There was initially no specific indication for tubercular infection but, as soon as the role of anti-TNF $\alpha$ agents in reactivating latent tuberculosis (TB) became clear, the patients had to be screened for the presence of past or latent TB (history, Mantoux test, chest radiography). TB-positive patients could be treated with infliximab only after at least three weeks of anti-TB therapy, 
Table I - Baseline demographic and clinical characteristic of the 1114 RA patients included in the LORHEN Register.

\begin{tabular}{|c|c|c|c|c|}
\hline & Etanercept & Adalimumab & Infliximab & Overall \\
\hline Patients, n (\%) & $249(22.4)$ & $332(29.8)$ & $533(47.8)$ & $1114(100)$ \\
\hline Mean age, years (SD) & $55.82(14.55)$ & $56.11(13.01)$ & $55.74(12.08)$ & $55.87(12.93)$ \\
\hline Females, n (\%) & $210(84.3)$ & $283(85.2)$ & $430(80.7)$ & $923(82.9)$ \\
\hline Males, n (\%) & $39(15.7)$ & $49(14.8)$ & $103(19.3)$ & $191(17.1)$ \\
\hline $\begin{array}{l}\text { Mean disease duration, } \\
\text { years (SD) }\end{array}$ & $9.61(7.17)$ & $9.47(7.89)$ & $9.22(6.97)$ & $9.38(7.29)$ \\
\hline Comorbidity, n (\%) & $82(32.9)$ & $132(39.8)$ & $209(39.2)$ & $423(38.0)$ \\
\hline \multicolumn{5}{|l|}{ Functional disability, n (\%) } \\
\hline I & $2(0.8)$ & $24(7.2)$ & $13(2.4)$ & $39(3.5)$ \\
\hline II & $176(70.7)$ & $241(72.6)$ & $327(61.4)$ & $744(66.8)$ \\
\hline III & $60(24.1)$ & $63(19.0)$ & $158(29.6)$ & $281(25.2)$ \\
\hline IV & $11(4.4)$ & $4(1.2)$ & $35(6.6)$ & $50(4.5)$ \\
\hline $\begin{array}{l}\text { Tuberculosis prophylaxis, } \\
\text { n (\%) }\end{array}$ & $48(19.3)$ & $49(14.8)$ & $51(9.6)$ & $148(13.3)$ \\
\hline $\begin{array}{l}\text { Mean number of } \\
\text { previous DMARDs (SD) }\end{array}$ & $2.99(1.24)$ & $3.00(1.16)$ & $3.10(1.22)$ & $3.04(1.21)$ \\
\hline $\begin{array}{l}\text { Concurrent } \\
\text { corticosteroids, n (\%) }\end{array}$ & $210(84.3)$ & $254(76.5)$ & $471(88.4)$ & $935(83.9)$ \\
\hline Concurrent NSAIDs, n (\%) & $71(28.5)$ & $89(26.8)$ & $121(22.7)$ & $281(25.2)$ \\
\hline Concurrent MTX, n (\%) & $177(71.1)$ & $245(73.8)$ & $512(96.1)$ & $934(83.8)$ \\
\hline $\begin{array}{l}\text { Other concurrent } \\
\text { DMARDs, } n(\%)\end{array}$ & $16(6.4)$ & $17(5.1)$ & $10(1.9)$ & $43(3.9)$ \\
\hline RF positive, n (\%) & $185(77.4)$ & $236(72.6)$ & $427(82.9)$ & $848(78.6)$ \\
\hline Mean anti-CCP (SD) & $79.23(78.82)$ & $93.12(184.59)$ & $65.86(49.09)$ & $79.07(121.43)$ \\
\hline Mean 28 SJC (SD) & $10.83(5.82)$ & $9.64(5.07)$ & $9.88(5.12)$ & $10.02(5.28)$ \\
\hline Mean 28 TJC (SD) & $11.38(6.79)$ & $10.30(6.11)$ & $11.87(6.31)$ & $11.29(6.39)$ \\
\hline Mean ESR, mm/h (SD) & $41.66(20.07)$ & $36.71(20.99)$ & $41.32(22.38)$ & $40.02(21.56)$ \\
\hline Mean CRP, mg/dl (SD) & $10.47(9.55)$ & $9.73(9.68)$ & $10.32(9.77)$ & $10.18(9.69)$ \\
\hline $\begin{array}{l}\text { Mean patient global } \\
\text { assessment (S.D.) }\end{array}$ & $64.98(14.26)$ & $62.61(14.68)$ & $58.47(20.15)$ & $60.54(18.12)$ \\
\hline Mean DAS 28 (SD) & $5.92(1.02)$ & $5.65(0.96)$ & $6.01(0.94)$ & $5.88(0.97)$ \\
\hline Mean PAIN, VAS (SD) & $75.21(14.36)$ & $70.42(19.52)$ & $79.95(12.31)$ & $75.51(16.04)$ \\
\hline Mean HAQ score (SD) & $1.41(0.63)$ & $1.25(0.55)$ & $1.60(0.61)$ & $1.45(0.61)$ \\
\hline
\end{tabular}


which had to be continued for at least nine months. The guidelines also included a recommendation that rheumatologists should register all treated patients in a national register in order to study long term safety.

Since 1999, all of the patients with RA diagnosed on the basis of the ACR criteria (6) and treated with at least one dose of an anti-TNF agent have been recorded in a database shared by four Rheumatology Centres in Lombardy (northern Italy): the Lombardy Rheumatology Network (LORHEN) registry.

\section{THE LORHEN REGISTRY}

This registry describes the efficacy and safety of the first three years of treatment in a large cohort of patients with RA treated with the three currently available TNF inhibitors: etanercept, infliximab and adalimumab (ETA, INF, ADA).

\section{Baseline}

All of the patients with rheumatic disease who start therapy with a biological agent are asked to give their consent to being entered in the registry, after which the consultant completes a standard baseline form including demographic data, the 1987 ACR criteria for RA (6), the individual components of the DAS28 (7), details of all previous and current DMARD therapy, and comorbidities; the registry does not collect radiological data. The are also asked to provide additional data concerning their smoking habits and occupational history, and to complete the Italian version of the Disability Index of the Health Assessment Questionnaire (HAQ) (8) and the Medical Outcome Survey Short Form 36 (SF-36) assessing the quality of life (9).

\section{Assessments}

At baseline, and after six and 12 months of followup, the treating rheumatologist records each patient's tender and swollen joint counts (28 joints), the patient's assessment of pain on a $100 \mathrm{~mm}$ visual analogue scale (VAS), the patient's overall assessment of general health on a $100 \mathrm{~mm}$ VAS, disability as measured by the Italian version of the HAQ, the erythrocyte sedimentation rate (ESR) measured using the Westergren method ( $\mathrm{mm} /$ hour), C-reactive protein (CRP) level, rheumatoid factor (RF), the presence of morning stiffness, the use of DMARDs and/or biological therapy (including details of the start and end of treatment and reasons for treatment termination), concomitant therapies with glucocorticosteroids or non-steroidal anti-inflammatory drugs (NSAIDs), and any adverse events.

In addition to being evaluated individually, these measures are also used to compute the DAS28 and to define patient response to treatment on the basis of the EULAR criteria $(7,10,11)$. The reasons for discontinuing anti-TNF therapy are classified into three major categories: adverse events, inefficacy (both primary lack of efficacy and secondary loss of efficacy), and other reasons. In the case of a switch from one TNF inhibitor to another, only the first course is considered.

\section{Follow-up}

All of the patients are followed up for three years, including those who stop therapy or switch to another biological agent, using three approaches:

- Every six months, the attending rheumatologists are asked to provide details of any changes in therapy, current disease activity (DAS28) and, specifically, the occurrence of any adverse event.

- The patients are surveyed every six months (for three years), and asked to complete a diary including any new diagnoses, significant comorbidities and serious adverse events (defined as any event leading to hospitalisation, whether or not it is associated with therapy).

- All of the patients are flagged with the Italian Office for National Statistics, which notifies the registry of: any death (with a copy of the medical information on the death certificate) and any cancer.

\section{Statistical analysis}

The data used for this report were statistically analysed using SPSS 15 for Windows software (SPSS Inc., ILL, USA).

\section{Results}

The registry only records the data collected at baseline, after six and 12 months, and then once a year; so far, only the data relating to the first 36 months have been validated. For the purposes of this study, we considered the 1010 patients who had been followed up for at least six months plus a further 54 who, although they had been followed up for a shorter time, had already discontinued anti-TNF therapy (intention-totreat approach) (Fig. 1).

The registry includes a total of 1114 patients: 533 $(47.8 \%)$ treated with infliximab, $332(29.8 \%)$ with 


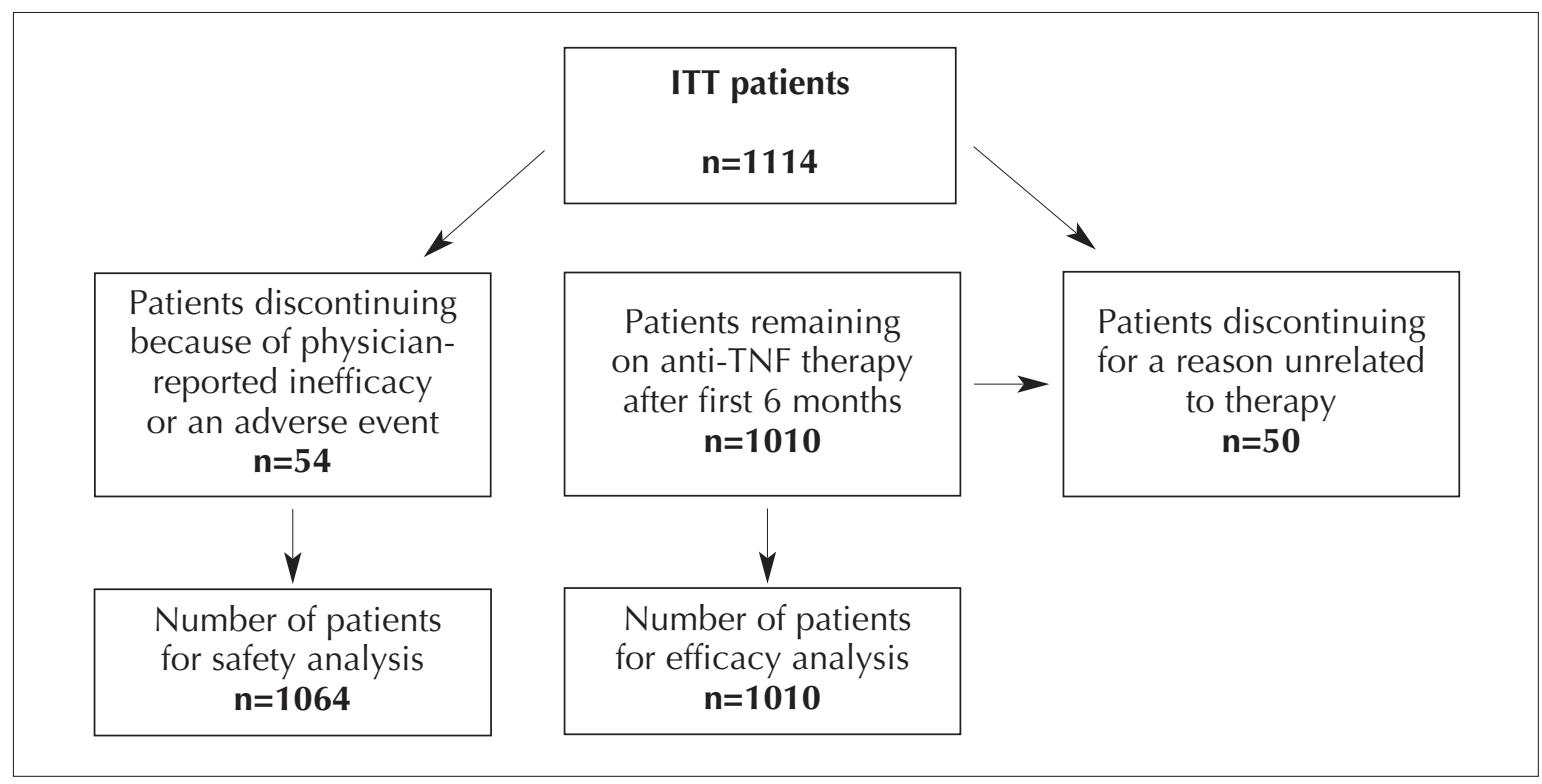

Figure I - Number of the patients included in the LORHEN registry.

adalimumab, and 249 (22.4\%) with etanercept. Table I shows their main demographic and clinical characteristics at the start of anti-TNF treatment. In brief, their mean age was 55.87 years and the mean duration of RA was 7.78 years; $78.6 \%$ were positive for rheumatoid factor (RF). More than $38 \%$ had comorbidities.

The median number of previous DMARDs was three per patient, the vast majority of whom had previously received MTX. In combination with the biological drug, $83.9 \%$ of the patients received steroids (mean dose $4.92 \mathrm{mg} /$ day), and $88.0 \%$ at least one DMARD $(83.8 \%$ methotrexate at a median dose of $12.35 \mathrm{mg} /$ week).

\section{OTHER REGISTRIES OF BIOLOGICAL AGENTS}

The introduction of new biological drugs for the treatment of RA and other rheumatic diseases has led to the implementation of specific registries in various countries, all of which are designed to track safety and efficacy. However, there are some differences between them.

The German Registry Rheumatoid Arthritis Observation of Biologic Therapy (RABBIT) is an ongoing, intensively monitored, observational cohort study: the RA patients who start treatment with any of the licensed biological agents are enrolled in the case group, and the control subjects are those monitored from the time they start a traditional
DMARD after the failure of at least one other DMARD (12).

The British Society for Rheumatology (BSR) registry is a nationwide registry of patients with any rheumatological disorder treated with biological agents that is intended to assess the long-term toxicity and benefits of their use (13). However, one specific characteristic of the BSR register is that it also includes data from RA patients treated with conventional DMARDs in order to be able to compare the results (14).

The BIOBADASER registry, which was established in February 2000 with the aim of actively monitoring the long-term efficacy and safety of biological response modifiers in Spanish rheumatic patients, includes about $60 \%$ of the total population treated in Spain, and first defined the guidelines for TB screening and treatment $(15,16)$.

The Swedish rheumatology register was the first to organise registries for RA patients: ARTIS (Antirheumatic Therapies in Sweden), SSATG (Southern Sweden Anti-rheumatic Therapy Group), and STURE (Stockholm Tumor Necrosis Factor Follow-up Registry). These have demonstrated that registries are not only extremely useful in evaluating the efficacy and safety of all of the drugs used to treat RA, but also in conducting scientific research studies of everyday practice (17).

The Consortium of Rheumatology Researchers of North America (CORRONA) Registry collects clinical practice data relating to patients with RA 
and psoriatic arthritis in order to evaluate their responses to biological agents (18).

Finally, the Czech National Registry has focused on radiographic progression in patients treated with anti-TNF agents, and reported that the improvement in everyday practice is similar to that shown by clinical trials (19).

\section{CONCLUSIONS}

The LORHEN registry data describe the efficacy and safety of the three currently available TNF inhibitors during the first three years of treatment in a large cohort of RA patients from Lombardy, Italy.

\section{SUMMARY}

Rheumatoid arthritis (RA) is a systemic autoimmune disease characterized by chronic synovitis and bone damages, which consist of joint destruction. Clinical trials have shown that anti-tumour necrosis factor (TNF) drugs are effective in patients with rheumatoid arthritis (RA) refractory to disease-modifying antirheumatic drugs (DMARDs). At about the same time as the European approval of the third anti-TNF agent for treating rheumatoid arthritis (RA) patients, the Italian Society of Rheumatology (Società Italiana di Reumatologia [SIR]) started a database for the registration and active follow-up of patients with RA treated with biological response modifiers. Since 1999, all patients with RA (ACR criteria) and treated with at least one dose of an anti-TNF agent at four Rheumatology Centres in Lombardy (northwest Italy) have been included in the Lombardy Rheumatology Network (LORHEN) registry in order to track the efficacy and safety of the three available TNF inhibitors during the first three years of treatment.

Key words - Lombardy Rheumatology Network (LORHEN) registry; rheumatoid arthritis; Italian Society of Rheumatology (Società Italiana di Reumatologia [SIR]).

Parole chiave - Registro Lombardy Rheumatology Network (LORHEN), artrite reumatoide, Società Italiana di Reumatologia (SIR).

\section{REFERENCES}

1. Maini R, St Clair EW, Breedveld F, Furst D, Kalden J, Weisman M, et al. Infliximab (chimeric anti-tumour necrosis factor alpha monoclonal antibody) versus placebo in rheumatoid arthritis patients receiving concomitant methotrexate: a randomised phase III trial. Lancet 1999; 354: 1932-9.

2. Moreland LW, Baumgartner SW, Schiff MH, Tindal EA, Fleischmann RM, Weaver AL, et al. Treatment of rheumatoid arthritis with a recombinant human tumour necrosis factor (p75)-Fc fusion protein. N Engl J Med 1997; 337: 141-7.

3. Weinblatt ME, Keystone EC, Furst DE, Moreland LW, Weisman MH, Birbara CA, et al. Adalimumab, a fully human anti-tumour necrosis factor $\alpha$ monoclonal antibody, for the treatment of rheumatoid arthritis in patients taking concomitant methotrexate: The ARMADA trial. Arthritis Rheum 2003; 48: 35-45.

4. Hamilton K, Clair EW. Tumour necrosis factor-alpha blockade: a new era for effective management of rheumatoid arthritis. Expert Opin Pharmacother 2000; 1: 1041-52.

5. Valesini G, Montecucco C, Cutolo M. Anti-TNF treatment for rheumatoid arthritis. Clin Exp Rheumatol 2006, 24: 413-23.

6. Arnett FC, Edworthy SM, Bloch DA, McShane DJ, Fries JF, Cooper NS, et al. The American Rheumatism Association 1987 revised criteria for the classification of rheumatoid arthritis. Arthritis Rheum 1988; 31: 315-24.

7. Van Riel PLCM, van Gestel AM, Scott DL, on behalf of the EULAR standing committee for international clinical studies including therapeutic trials. The EULAR handbook of clinical assessment in rheumatoid arthritis. Alpen an den Rijn, The Netherlands: Van Zuiden Communications, 2000.

8. Ranza R, Marchesoni A, Calori G, Bianchi G, Braga M, Canazza S, et al. The Italian version of the functional disability index of the Health Assessment Questionnaire. A reliable instrument for multicenter studies in rheumatoid arthritis. Clin Exp Rheumatol 1993; 11: 123-8.

9. Apolone G, Moscone P. Come usare il questionario sullo stato di salute SF-36 (versione italiana). Progetto IQOLA. Istituto di Ricerche Farmacologiche "Mario Negri”, 1996.

10. Fransen J, Creemers MC, van Riel PL. Remission in rheumatoid arthritis: agreement of the disease activity score (DAS28) with the ARA preliminary remission criteria. Rheumatology 2004; 43: 1252-5.

11. Makinen H, Kautiainen H, Hannonen P, Sokka T. Is DAS28 an appropriate tool to assess remission in rheumatoid arthritis? Ann Rheum Dis 2005; 64: 1410-3.

12. Listing J, Strangfeld A, Rau R, Kekow J, Gromnica-Ihle E, Klopsch T, Demary W, Burnester GR, Zink A. Clinical and functional remission: even though biologics are superior to conventional DMARD overall success rates remain low - results from RABBIT, the German 
biologics register. Arthritis Res Ther 2006; 8(3): R66. 13. Silman A, Symmons D, Scott DGI, Griffiths I. British Society for Rheumatology Biologics Register. Ann Rheum Dis 2003; 62 (Suppl. II): ii28-ii29.

14. Hyrich KL, Watson KD, Silman AJ, Symmons DP. British Society for Rheumatology Biologics Register Predictors of response to anti-TNF-alpha therapy among patients with rheumatoid arthritis: results from the British Society for Rheumatology Biologics Register. Rheumatology (Oxford) 2006; 45: 1558-65.

15. Gómez-Reino JJ, Carmona L, Valverde VR, Mola EM, Montero MD, for the BIOBADASER Group. Treatment of rheumatoid arthritis with tumor necrosis factor inhibitors may predispose to significant increase in tuberculosis risk: a multicenter active-surveillance report. Arthritis Rheum 2003; 48: 2122-7.
16. Carmona L, Gomez-Reino JJ, Rodriguez-Valverde V, Montero D, Pascual-Gomez E, Mola EM, et al. Effectiveness of recommendations to prevent reactivation of latent tuberculosis infection in patients treated with tumor necrosis factor antagonists. Arthritis Rheum 2005; 52:1766-72.

17. Van Vollenhoven RF, Askling J. Rheumatoid arthritis registers in Sweden. Clin Exp Rheum 2005; 23 (Suppl 39): S195-S200.

18. Kremer JM. The CORRONA database. Clin Exp Rheumatol 2005; 23 (Suppl. 39): S172-7.

19. Pavelka K, Gatterova J, Tegzova D, Jarasova K, Tomasova Studynkova J, et al.. Radiographic progression of rheumatoid arthritis in patients from the Czech National Registry receiving infliximab treatment. Clin Exp Rheum 2007; 25: 540-5. 